\title{
Status of Fish Assemblage Structure in the Garmat Ali River, Iraq
}

\author{
Abdul-Razak M. Mohamed ${ }^{1}$, Kadim H. Younis ${ }^{2}$ and Entisar K. Hameed ${ }^{2}$ \\ 'Department of Fisheries and Marine Resources, College of Agriculture \\ Basrah University, Ira \\ ${ }^{2}$ Department of Marine Vertebrates, Marine Science Centre, Basrah University, Iraq
}

\begin{abstract}
The status of fish assemblage structure in Garmat Ali River, north of Basrah, Iraq was assessed. Fish were sampled monthly by different fishing gears from November 2015 to October 2016. Water temperature varied from $14.3^{\circ} \mathrm{C}$ in December to $32.7^{\circ} \mathrm{C}$ in September, and salinity ranged from $1.5 \%$ in June to $6.0 \%$ in December. A total 34 fish species belonging to 16 families were collected, 7 of them were native, 8 exotic and 19 marine species. The most abundant species were Poecilia latipinna, comprising $57.66 \%$ of the total catch, Tenualosa ilisha (15.29\%) and Thryssa whiteheadi (7.96\%). The dominance value (D3) was $80.9 \%$. These results were contrasted with the past findings on the river. The mean annual values of diversity, richness and evenness indices were 1.91, 2.95 and 0.76, respectively. Associations between the distribution of fish species and the environmental variables were quantified by using canonical correspondence analysis (CCA).
\end{abstract}

Keywords: Fish assemblage, ecological factors, biodiversity indices, Garmat Ali, Iraq

\section{Introduction}

Over the past years, the rivers have been increasingly subjected to the cumulative effects of anthropogenic disturbances such as point-source pollution, urbanization, agriculture, channel modification, impoundment, and nonnative species introductions. These human disturbances have directly and indirectly influenced fish assemblage structure by altering flow regimes, degrading water quality and habitat structure, disrupting energy inputs, shifting biotic interactions (Parks, et al., 2014).

The Garmat Ali River was subjected to multiple impacts from hydrological and human activities. After inundation of the southern marshes in 2003, the East Hammar marsh was fed primarily from the Euphrates River and entering the Garmat Ali River then the Shatt Al-Arab River that eventually flows into the Arabian Gulf. So, this river affected by the water from the Euphrates and tidal current of the Gulf through the Shatt AlArab River. But, the flow of the Euphrates was diverted away from the north East Hammar marsh during the last years, consequently the water level in the marsh dropped sharply, causing the water salinity higher than before, which led to negatively affected on water quality and quantity of the Garmat Ali River (Al-Tememi, et al., 2015).

Moreover, the Shatt Al-Arab River suffered from massive regression in water quality related to the decline in rates of discharge from the Tigris and the Euphrates Rivers (Al-Mahmood, et al., 2015) as a result of several hydrological projects constructed in the riparian countries (Partow, 2001), and the diversion of the Karun River into Iranian terrene (Hameed and Aljorany 2011). The average rate of discharge in the upstream of the Shatt-Al-Arab River was declined from $207 \mathrm{~m}^{3} / \mathrm{s}$ during $1977-1978$ to $60 \mathrm{~m}^{3} / \mathrm{s}$ during 2014 (Alaidani, 2014). Several studies have been supportive of the deterioration of the Shatt al-Arab water quality which attributed to reduced freshwater discharges from Tigris and Euphrates Rivers and the negative impact of salt intrusion from the Arabian Gulf over the past decade (Brandimarte, et al., 2015; Moyel and Hussain, 2015; Yaseen, et al., 2016). The specific objective of this study is to describe the status of fish assemblage structure of the Garmat Ali River and then to compare this with the state of the fish assemblage in this river before a decade.

\section{Materials and Methods}

The study was carried out in the Garmat Alit Ali River, situated in the north of Basrah city, and is a waterway between the east Hammar marsh and the Shatt Al-Arab River (Fig. 1). The total length of the river is about $6 \mathrm{~km}, 280 \mathrm{~m}$ width and the mean depth is $9 \mathrm{~m}$. The river is affected by the tidal current of the Arabian Gulf. Sampling on the river was conducted once a month from November 2015 to October 2016. Three sampling sites were selected: site 1 is located at the junction of the river with Shatt Al-Arab River, whereas site 2 is located north Garmat Ali Bridge and site 3 is located at the confluence of the river with the East Hammar marsh (Al-Mas'hab waterway). The predominant vegetations on the banks were Phragmites australis, and Typha domingensis, whereas Ceratophyllum demersum was dominant in the deeper areas.

Water temperature, salinity and $\mathrm{pH}$ were measured in situ using YSI portable instrument model 556 MPS. Transparency was evaluated by extinction method using the Secchi disc. Fish sampling was carried out 
from each station using seine net ( $140 \mathrm{~m}$ long with a $36 \mathrm{~mm}$ mesh size), fixed gill nets $(120 \mathrm{~m}$ long with $2.5 \mathrm{~cm}$ to $10 \mathrm{~cm}$ mesh size) and electro- fishing gear (provides $300-400 \mathrm{~V}, 3-5 \mathrm{~A}$ ). Fishes were counted and classified to species following Carpenter et al. (1997), Durand, et al. (2012) and Coad (2017).

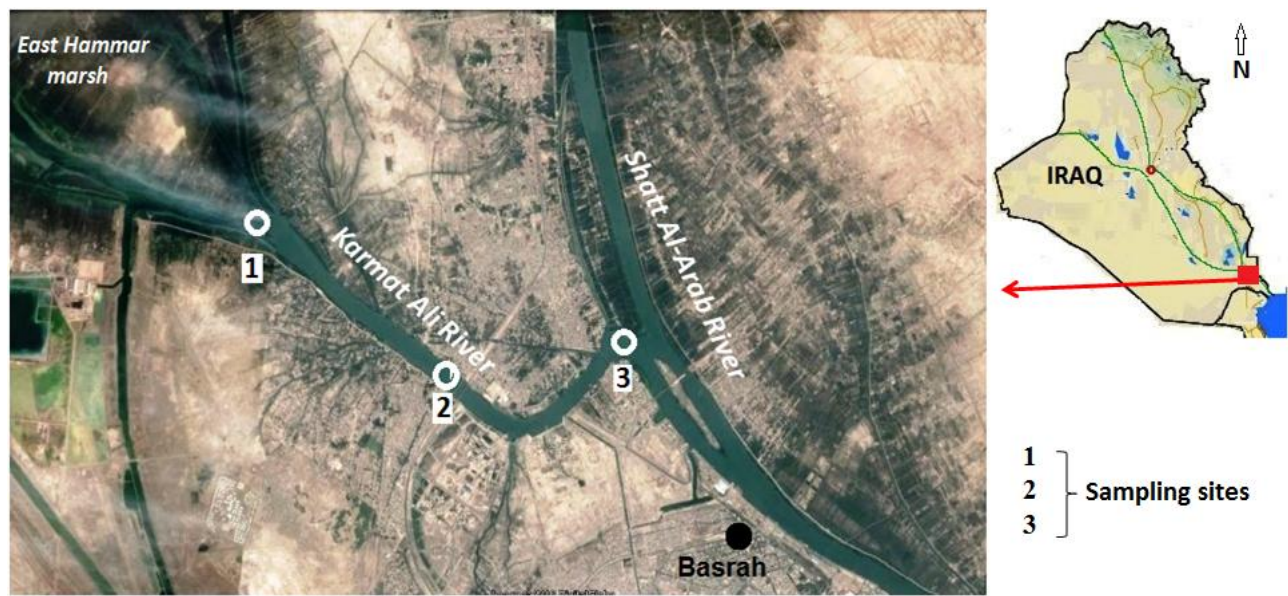

Fig.1. Map of southern of Iraq showing the sampling sites in the Garmat Ali River

The relative abundance was calculated from the equation $n_{i} / N \times 100$ (Odum, 1970), where $n_{i}$ is the number of individuals of ' $\mathrm{i}$ th' species and $N=\Sigma n_{i}$. Shannon-Weaver index of diversity was obtained by the following equation $H^{\prime}=-\sum p_{i} \ln p_{i}$ (Shannon and Weaver, 1949), where $p_{i}=n_{i} / N ; n_{i}$ is the number of individuals of ' $i$ 'th species and $N=\Sigma n_{i}$. The species richness was calculated using the equation $D=(S-1) / l n N$ (Margalef, 1968), where $S$ is the number of species, $N$ is the total number of individuals. The evenness is $J=H^{\prime} / \ln S$ (Pielou, 1977), where $H^{\prime}$ is the diversity and $\mathrm{S}$ is the number of species. The three most abundant species was determined by the following equation $D_{3}=\left[\sum_{i=1}^{3}\right.$ pi.] 100 (Kwak and Peterson, 2007), where $P_{i}$ is the proportion of the total sample represented by the $\mathrm{i}^{\text {th }}$ species.

All statistical analyses were performed using the SPSS version 16 for Windows. The multiple linear correlation analysis was carried out on water parameters and fish to verify if there is any significant relationship by applying the multivariate analysis of ecological data using CANOCO program (Ter Braak, 1986).

\section{Ecological factors}

\section{Results}

Water temperature, salinity, transparency and $\mathrm{pH}$ were not significantly differences between the three sampling stations $(F=0.47,0.81,0.33$ and $0.20, p \leq 0.05)$, respectively. Therefore, the monthly variations in the mean values of these factors in the river are shown in Figure 2. The water temperature in this study varied from the lowest value $\left(14.3^{\circ} \mathrm{C}\right)$ which recorded during December to the highest value $\left(32.7^{\circ} \mathrm{C}\right)$ recorded during September, with overall value 23.5 . The values of salinity ranged from $1.5 \%$ in June to $6.0 \%$ in December, with overall value 2.8 . Transparency values varied from $17.7 \mathrm{~cm}$ in July to $55.0 \mathrm{~cm}$ in January, with overall value 29.9. Narrow fluctuation of $\mathrm{pH}$ was observed during the study period, with the highest average value of 8.3 was recorded during November and a low of 7.2, with overall value 7.7.

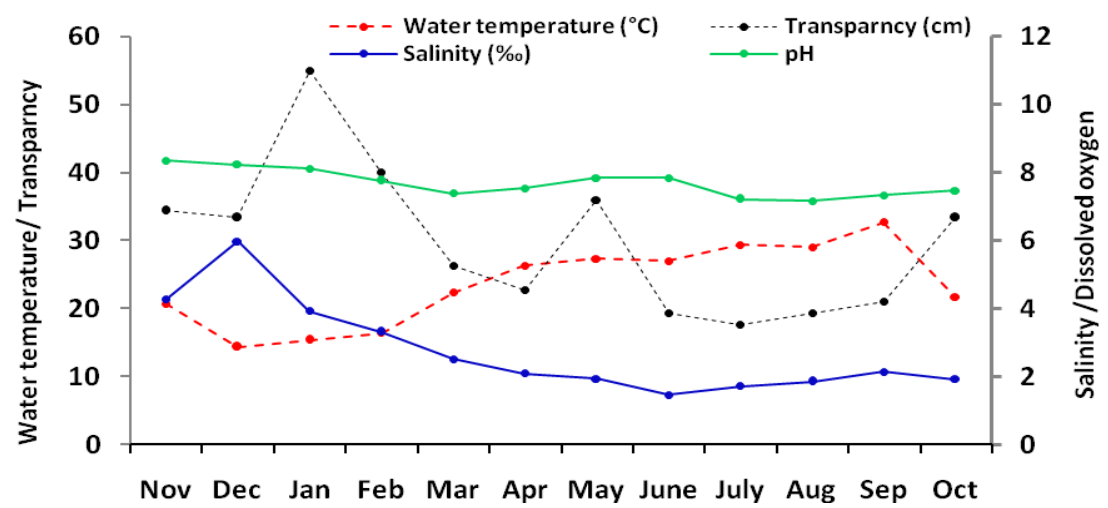

Fig. 2. Monthly variations in the some ecological factors of the Garmat Ali River 


\section{Species composition}

Altogether, thirty four fish species belonging to 16 families were collected from three stations in the river (Table 1). Cyprinidae was the most dominated family in terms of number of species represented by seven species,

Table 1. Monthly variations in relative abundance of fish species collected from the Garma River (* Native, + Migratory, ${ }^{\circ}$ Exotic)

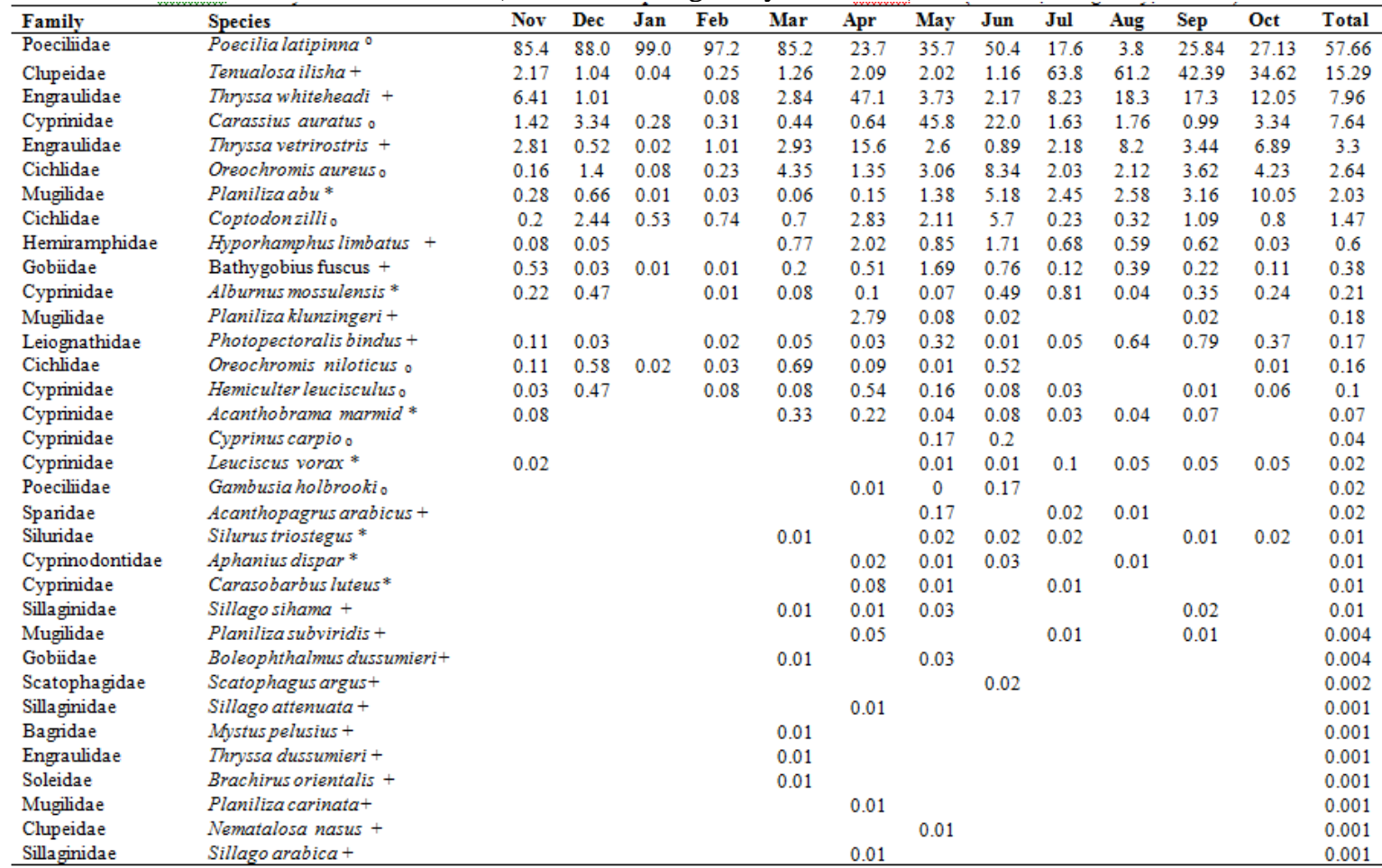

followed by Mugilidae (4 species), and Engraulidae, Cichlidae and Sillaginidae (3 species) each. Other families were contained one species each.

The monthly fluctuations in the number and individuals of species in the river are shown in Figure 3 . The number of species ranged from 9 in January to 27 in May. Generally, the number of species captured increased during March to June. A total of 141437 fish were caught from the river, they ranged from 3650 in December to 23313 fish in February.

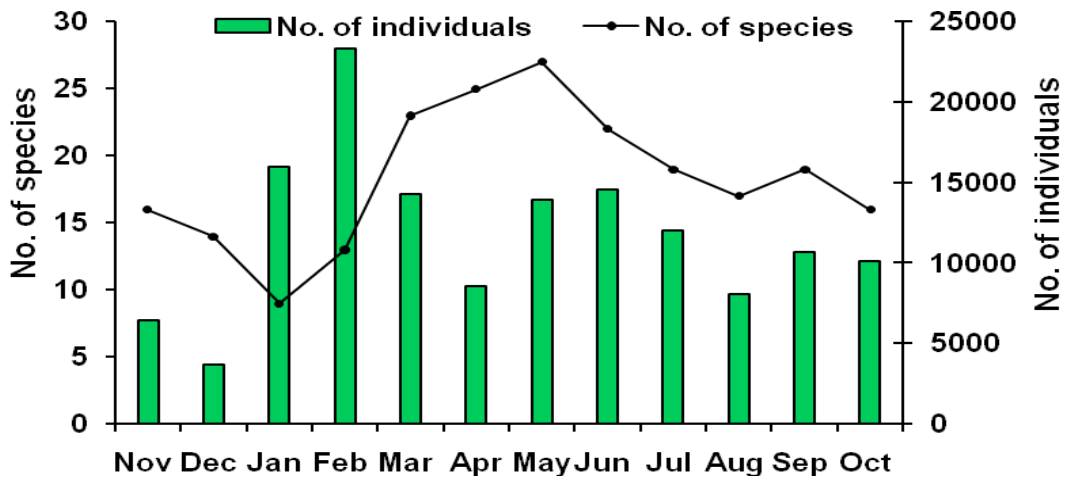

Fig. 3. Monthly variations in the number of species and individuals in the Garmat Ali River

The fish fauna of the river comprised of seven native, eight exotic and 19 marine species. The monthly variations in these categories are given in Figure 4. The native species constituted $20.6 \%$ of the total number of species and varied from one species in January to seven species in May, whereas the exotic species formed 23.5\% and changed from five species in January, July and August to eight species in May and June. The migratory species consisted $55.9 \%$ of the total number of species and varied from three species in January to 13 species in April. 


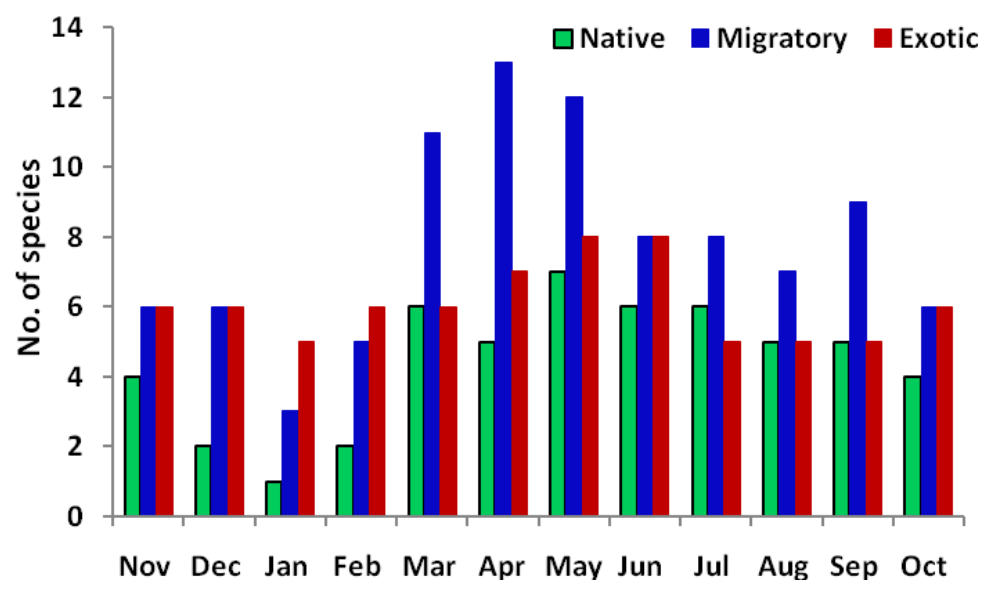

Fig. 4. Monthly variations in the number of native, migratory and exotic species in the Garmat Ali River

\section{Relative abundance}

The relative abundance of species in the Garmat Ali River during the study period are given in Table 1. It has been found that the fish assemblage was dominated by Poecilia latipinna, composed of 57.66\% of the total catch, it varied from 3.8\% in August to $99.0 \%$ in January. Tenualosa ilisha comprising $15.29 \%$ of the total catch, it fluctuated from $0.04 \%$ in January to $63.8 \%$ in July. Thryssa whiteheadi was formed $7.96 \%$ and the relative abundance ranged from $0.08 \%$ in February to $47.1 \%$ in April. These three species formed $80.9 \%$ of the total catch of species according to dominance index $\left(\mathrm{D}_{3}\right)$. However, Carassius auratus and Planiliza liza constituted only 7.64 and $2.03 \%$ from the total catch, respectively.

\section{Fish diversity indices}

Monthly variations in diversity, richness and evenness indices of fish assemblage in the river are illustrated in Figure 5. The diversity index $(H)$ fluctuated from 0.47 in February to 1.66 in October, with overall value 1.91. The richness index $(D)$ changed from 1.05 in February to 2.26 in April, with overvalue 2.95. The evenness index $(J)$ ranged from 0.23 in February to 0.63 in October, with overall value 0.76 .

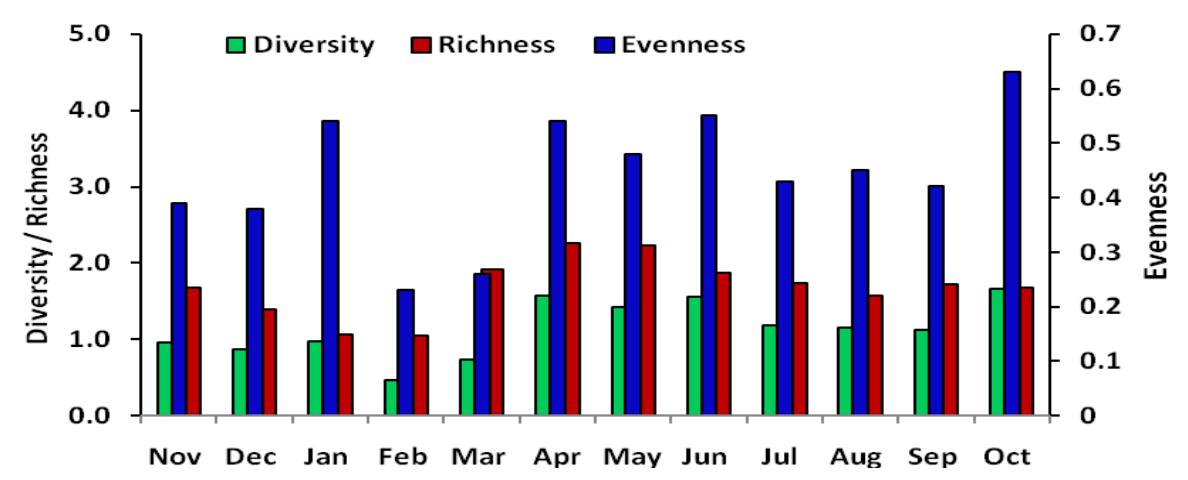

Fig. 5. Monthly variations in the ecological indices values of the Garmat Ali River

\section{Relationships of fish with the ecological factors}

Figure 7 illustrated the canonical correspondence analysis (CCA) ordination plot which summarized the relationships between the availability of the most numerous fish species and the environmental variables in the Garmat Ali River. The number of species and the following species Thryssa vetrirostris, T. whiteheadi, Oreochromis aureus, P. abu, Coptodon zilli, C. auratus and T. ilisha) were positively correlated with water temperature, and negatively correlated with salinity and transparency, except $P$. latipinna. 


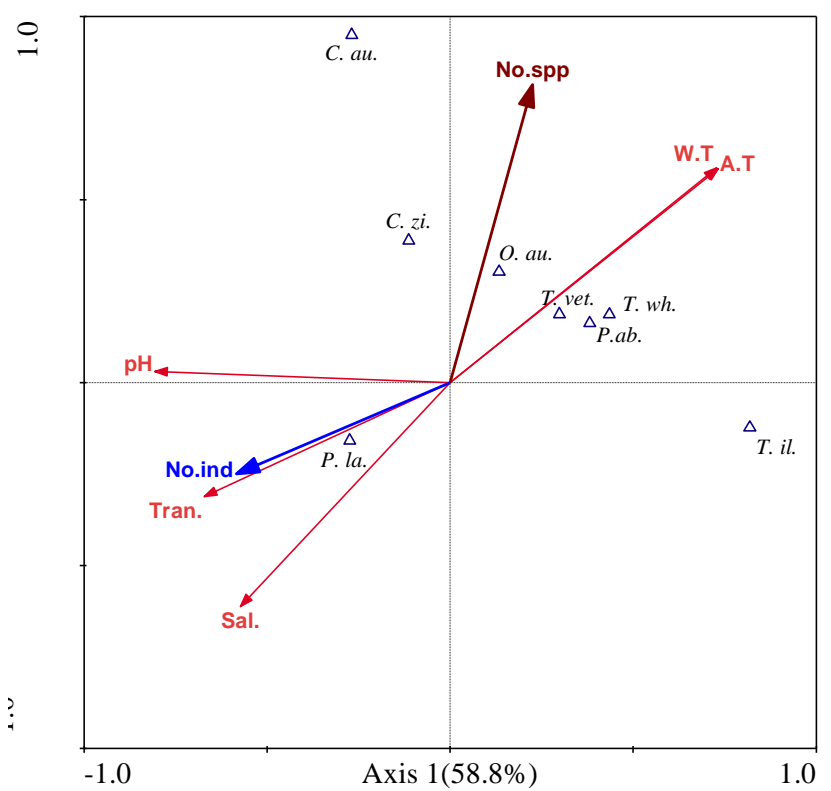

Fig. 5: CCA ordination plots showing the relationship among fish species and various ecological factors in the Garmat Ali River

\section{Discussion}

The results of this study revealed that the fish assemblage was clearly shifted in the percents of exotic and marine species, the dominancy species and the fish diversity compared with the previous status. The fish fauna of the river comprised of seven native, eight exotic and 19 marine species, constituted 20.6, 23.5 and $55.9 \%$ of total number of species, respectively. P. latipinna, T. ilisha, and T. whiteheadi were most abundant species, comprising 57.66, 15.29 and $7.96 \%$ of the total catch, respectively. These results were contrasted with the past findings reported earlier on the river. Younis et al. (2010) collected 28 fish species from the river during 2003-2004, 13 species were native freshwater, representing 46.4\% of the total number of species, 10 marine species consisted $35.7 \%$ and five exotic species formed $17.9 \%$. The most abundant species during this period were $L . a b u$ and $C$. auratus constituting 58.8 and $11.72 \%$ of the total catch, respectively. Moreover, Mohamed et al. (2013) recorded 25 fish species from the river during 2007-2008, 10 (38.5\%) of them were native, 10 (38.5\%) marine and $6(23.1 \%)$ exotic species, and the most abundant species were L. abu, C. auratus and P. latipinna constituting 39.3, 21.2 and 7.0\% of the total catch, respectively. However, Mohamed, et al. (2014) mentioned that the fish assemblage in the East Hammar marsh during 2012 -2013 was dominated by exotic species of which $C$. auratus comprised $22.1 \%$ followed by $P$. latipinna (14.3\%), while, $P$. abu and $C$. zilli (a new exotic species) formed $13.4 \%$ and $5.1 \%$, respectively.

This could be as a result of unfavorable environmental parameters, especially higher salinity and the changes in hydrological conditions. Formerly, the ranges of salinity in the river were 1.33-2.35\% during 20032004 (Younis et al., 2010) and 1.2-3.18\%o during 2007-2008 (Mohamed et al., 2013), whereas in the present study was 1.5-6.0\%o. During the last years, water influx the river was coming primarily from the Shatt Al-Arab River which affected by the tidal current of the Arabian Gulf. Several studies have been supportive of the deterioration of the Shatt al-Arab water quality in recent years (Al-Tawash, et al., 2013; Brandimarte, et al., 2015; Moyel and Hussain, 2015; Yaseen, et al., 2016).

The degradation of water quality of the southern water led to several cyprinid species disappearance or substantially decreased in abundance, such as Luciobarbus xanthopetrus, Arabibarbus grypus, Luciobarbus kersin, Mesopotamichthys sharpeyi and Carasobarbus luteus (Richardson, et al., 2005; Mohamed, et al., 2012, 2013). Hughes and Whittier (2005) mentioned that native species represent the basic building blocks of a fish assemblage, and are a key component of diversity and the exotic species indicate biological pollution and a serious diversion from natural conditions, especially when they constitute a substantial percentage of the assemblage, and including when they are deliberately introduced. The extremely tolerant species are the last to disappear in response do environmental degradation (Costa and Schulz 2010). Researchers have commonly observed habitat degradation facilitating the underlying mechanisms causing the loss of native fish diversity, the temporal replacement of specialized native fish by exotic fish (Scott and Helfman, 2001; Olden and Poff, 2003; Parks, et al., 2014).

There were seasonal changes in fish diversity in the river and the richness indices had a general tendency to show high values during the period from March to July which could be attributed largely to the penetration of marine species especially anadromous species, such as T. ilisha and T. whiteheadi, corresponding 
with increased in water temperature and decreased in salinity. This result is supported by the positive correlations between the number of species and abundances of all species, except the exotic species, P. latipinna with water temperature, and the negative correlations with salinity. The abundance of marine species has led to an increase in the richness, evenness and diversity indices and created seasonal fluctuation in the relative abundance (Hussain, et al., 1989). This was comparable to the previous studies on the East Hammar marsh and the river (Mohamed et al., 2009, 2013; Younis et al., 2010).

\section{Conclusions}

The present study shows that the fish structure of the Garmat Ali River was clearly altered by increase percents of exotic and marine species, and decline in native species compare with the state of the fish assemblage of this river before a decade.

\section{References}

[1]. T.P. Parks, M.C. Quist and C. L. Pierce, Historical Changes in Fish Assemblage Structure in Midwestern Nonwadeable Rivers Am. Midl. Nat. 171, 2014, 27-53.

[2]. M.K. Al-Tememi, M.A. Hussein, U.Q. Khaleefa, H.B. Ghaleb, A.M. AL-Mayah and A.J. Ruhmah, The Salts diffusion between East Hammar marsh area and Shatt Al-Arab River Northern Basra City. Marsh Bulletin, 10, 2105, 36-45.

[3]. H.K.H. Al-Mahmood, W.F. Hassan, A.Z.A. Alhello, A.I. Hammood and N.K. Muhson, Impact of low discharge and drought of the water quality of the Shatt Al Arab and Al-Basrah Rivers (south of Iraq). J. Int. Acad. Res. Multidisciplinary. 3, 2015, $285-296$.

[4]. H. Partow, The Mesopotamian Marshlands: Demise of an Ecosystem. Early Warning and Assessment Technical Report, UNEP/DEWA/TR.01-3 Rev. 1, 2001

[5]. A. H. Hameed and Y. S. Aljorany, Investigation on nutrient behavior along Shatt Al-Arab River River, Basrah, Iraq. J. Appl. Sci. Res., 7, 2011, 1340-1345.

[6]. M.A.T. Alaidani, The change in the geographic and agricultural properties impacts in the province of Basra, MSc. Thesis, University of Basra, College of Education Sciences, 2014.

[7]. L. Brandimarte, I. Popescu and N.K. Neamah, Analysis of fresh-saline water interface at the Shatt Al-Arab estuary. International Journal of River Basin Management. 13, 2015, 17-25.

[8]. M.S. Moyel and N.A Hussain, Water quality assessment of the Shatt al-Arab River, Southern Iraq. Journal of Coastal Life Medicine. 3, 2015, 459-465.

[9]. B.R. Yaseen, K.A. Al-Asaady, A.A. Kazem and M.T. Chaichan, Environmental Impacts of Salt Tide in Shatt Al-Arab-Basra/Iraq. Journal of Environmental Science, Toxicology and Food Technology. 10, 2016, 35-43.

[10]. K. E. Carpenter,F. Krupp, D.A. Jones and U. Zajonz, FAO species identification field guide for fishery purposes. Living marine resources of Kuwait, Eastern Saudi Arabia, Bahrain, Qatar and the United Arab Emirates. FAO, Rome, 1997, 293 p.

[11]. J.D. Durand, W.J. Chen, K.N. Shen, C. Fu and P. Borsa, Genus-level taxonomic changes implied by the mitochondrial phylogeny of grey mullets (Teleostei: Mugilidae). Comp. Rend. Biol. 335, 2012, 687-697.

[12]. W.B. Coad, Freshwater Fishes of Iraq. 2017, www.briancoad.com.

[13]. W.A. Odum, Insidious alternation of the estuarine environment. Trans. Am. Fish. Soc. 99, 1970, 836-847.

[14]. C.E. Shanon and W. Weaver, The mathematical theory of communication. Univ. Illionis. Press Urbane, 1949.

[15]. R. Margalef, Perspectives in ecology. University of Chicago Press, 1968.

[16]. E.C. Pielou, Mathematical ecology. John Wiely, New York, 1977.

[17]. T.J. Kwak and J.T. Peterson, Community indices, parameters, and comparisons. Analysis and interpretation of freshwater fisheries data. American Fisheries Society, Bethesda, Maryland, 2007, 677-763.

[18]. C.J.F. Ter Braak, Canonical Correspondence Analysis: A new eigenvector technique for multivariate direct gradient analysis. Ecology 67, 1986, 1167-1179.

[19]. K.H. Younis, N.A Hussain and A.R.M. Mohamed, Ecological Assessment of Fish Assemblage in Shatt Al-Arab River /Karmat Ali, Basrah Using Integrated Biological Index (IBI). Journal of the University of Karbala (special issued, 2010), 22-31.

[20]. A.R.M. Mohamed, S.A. Hussein and L.F. Lazem, Fish assemblage of Garmat Ali River, north of Basrah, Iraq. Agric. Sci. 26, 2013, $150-166$.

[21]. A.R.M. Mohamed, A.A. Al-Saboonchi and F.K. Raadi, Variability of fish assemblage structure in the East Hammar marsh, southern Iraq. JKAU: Mar. Sci., 25, 2014, 161-184.

[22]. B. Al-Tawash, H.S. Al-Lafta and B. Merkel, Preliminary Assessment of Shatt Al-Arab Riverine Environment, Basra Governorate, Southern Iraq. Journal of Natural Science Research. 3, 2013, 120-136.

[23]. C.J. Richardson, P. Reiss, N.A Hussain, A.J. Alwash and D.J. Pool, The restoration potential of the Mesopotamian marshes of Iraq Science 307, 2005. 1307-1311.

[24]. A.R.M. Mohamed, N.A Hussain, S. S. Al-Noor and F. M. Mutlak, Ecological and biological aspects of fish assemblage in the Chybayish marsh, Southern Iraq. Ecohydrology \& Hydrobiology, 12, 2012, 65-74.

[25]. R.M. Hughes, R. Thomas and T.R. Whittier, Biological Condition Index Development for the Lower Truckee River and Eastern Sierra Nevada Rivers: Fish Assemblage. Department of Fisheries and Wildlife, Oregon State University, Corvallis, Oregon, USA, 2005, 80p.

[26]. P. Costa. and U. Schulz, The fish community as an indicator of biotic integrity of the streams in the Sinos River basin, Brazil. Braz. J. Biol., 70, 2010, 1195-1205.

[27]. M. C. Scott and G. S. Helfman, Native invasions, homogenization, and the mismeasure of integrity of fish assemblages. Fisheries, 26, 2001, 6-15.

[28]. J. D. Olden and N. L. Poff, Toward a mechanistic understanding and prediction of biotic homogenization. Am. Nat. $162,2003$. $442-460$.

[29]. N.A Hussain, T.S, Ali and K.D. Soud, Seasonal fluctuations and composition of fish assemblage in the Shatt-Al-Arab River at Basrah, Iraq. J. Biol. Sc. Res. 20, 1989, 139-150.

[30]. A.R.M. Mohamed, N.A. Hussain, S. S. Al-Noor, B.W. Coad and F. M. Mutlak, Status of diadromous fish species in the restored East Hammar Marsh in Southern Iraq. Amer. Fish. Soc., 69, 2009. 577-588. 